\title{
The Legal Analyze of the Embezzlement in the Punitive System of Iran
}

\author{
Amir Kondori ${ }^{*}$ \\ Mohammad Mahdipour2 \\ Davood Seify ${ }^{3}$
}

Hamid Mirzaee ${ }^{4}$

\begin{abstract}
${ }^{*}$ Department Of Law, Faculty of Literature And Human Sciences, University of zabol, Zabol, Iran ${ }^{2}$ Department Of Law, Faculty of Literature and Human Sciences, University of zabol, Zabol, Iran ${ }^{3}$ Department Of Law, Faculty of Literature And Human Sciences, University of zabol, Zabol, Iran ${ }^{4}$ Department Of Law, Faculty of Literature and Human Sciences, University of tehran, tehran, Iran ${ }^{*}$ Corresponding author: Amir Kondori, Email: kondori.amir@hotmail.com
\end{abstract}

Doi:10.5901/mjss.2015.v6n5p44

\section{Abstract}

The embezzlement of public property is considered as the infringement of government personnel or personnel related to the government, the property of government or other individuals, which is considered as a serious threat against the government and nation. Although the penalty of embezzlement in Iran is execution, but still the rate of committing this crime is high. From the viewpoint of Iran's law, embezzlement is an intentional crime which its corporeal element is a positive action and it doesn't come off by the abandonment of the action. The criterion for the realization of embezzlement crime is the appropriation of the property and the proprietary act with the property which beside the movable properties which belong to private individuals and government property, it can also be generalized to the immovability properties. The property of the subject should be given to the employee with the appropriateness of his job and the property owner should receive the damage. Investigating legal texts and procedures indicates that judging rules of embezzlement and especially its punishment is in contrast with the legality principles. In this study the bases of abstraction crime in Iran will be investigated. This study is an applied research and in descriptive method. The required information was collected with documentation and Library. The first chapter of this study is about the legal pillar of the embezzlement and the second and third chapters are dedicated to the corporeal and moral pillars of this crime.

Keywords: embezzlement, betraying trusteeship, Iran's law, Crime

\section{Introduction}

The embezzlement of general property was discussed along with the forming of governments and is as old as the governments itself, and it is also considered as a threat to the whole human society. In our country, despite the intensification of the punishment of embezzlement, its perpetration still continues in a large scale. In order to prevent the employees from abusing general and government property and guaranteeing the benefits of the government the legislators have issued a law in order to positively protect the general property with the name of embezzlement.

One of the financial and unforgivable crimes is embezzlement, which the legislator in the maxim 4, of fundamental law will bound the government to take back the fortunes of embezzlement and return them to the government or the right owner and in cases 5 and 6 the intensification of the punishments by the people who commit embezzlement, bribery and fraud has been authorized by the assembly of recognizing the benefit of the system in June, 28th of 1985 . The legislators have defined some terms in order to define the meaning of embezzlement in which we will refer to some of them. Some defined embezzlement as "the changing of the defective possessions to an effective possession which is referred to as the "animus possidendi" or the "ownership intention" (Altar, Beta). This definition lack description and doesn't contain the characteristics of the crime committer and it includes the betraying of trusteeship. In another definition it has been mentioned that the embezzlement is an act in which the public employee or someone in his commandment start to take over the movable property, papers or other things which are given to him in accordance with his duty and he has no right to possess them (Saleh, 1992). Based on article 5 of intensifying the punishment for the committers of embezzlement, bribery and fraud, we can define the mentioned crime as the following "the act of the government employee or someone 
is his command in taking over the property which is given to him in accordance with his job, whether it is for the benefit of himself or the others".

\section{Legal Element}

For the first time the Iranian legislators have determined the meaning of embezzlement in article 152 of public punishment law in 1925. Then, after the victory of the Islamic revolution in 1983 and the approval of a new law, the articles 75 and 76 of the new law have been replaced respectively by articles 152 and 153 of the public punishment law, in which article 75 was the supervisor of embezzlement. Then, by the approval of the intensification of embezzlement, bribery and fraud crime punishment in 1997, the legislator has intensified the punishment of embezzlement through the article 5 of this law. Therefore, the legal pillar of embezzlement is the article 5 of the law of intensifying the punishment of embezzlement, bribery and fraud crime (Goldozian, 2013).

\section{Financial Element: Criminal Act}

\subsection{Withdrawal and appropriation}

The legislator has used the term "withdrawal, appropriation and purposely waste" for the term embezzlement in article 152 of curative law which has been approved in 1976. In the provisions which have been approved after the Islamic revolution these types of expressions were used, but in the provision of article 5 of intensification of embezzlement, bribery and fraud law, the legislator has considered the purposeful wasting of money apart from withdrawal and appropriation and has considered its punishment equal with the punishment of embezzlement. The legislator has expressed the expression of criminal act with the term "withdrawal and appropriation", but we can't infer from this term, that the criminal act in this crime is consist of two parts, rather it seems that because embezzlement in most cases is performed by the people who are dealing with money, therefore the legislator has used the terms withdrawal and appropriation with the same meaning. It means that he considered both of them as the possession or the possessive behavior of the money, but he considered the withdrawal as the supervisor of proprietorship and appropriation as the supervisor of the possessive behavior of other properties. The term "withdrawal" is a term which nowadays mostly used in bank procedures such as money exchange and transfer, therefore when legislator use this word he refers to the possession of the cash and consider the spending of the withdrawal as a prove to the possession of that cash (Vahidi, 2012). Most jurists believe that the criminal act in abbreviation can be changed by altering the type of possession, it means that the criminal act with the possessed money as if the money belong to him, in another expression the criminal should appear as the owner of the property and introduce himself as the owner (Omar mosa, 1991; Hosni najib, 1992). This kind of behavior can be reflected in many forms, such as selling, donating, hiding, putting to sale, wasting or any other action which indicates that the property belong to himself. Therefore, the criterion for the committing of embezzlement crime is "to take over and own the property". Also, in this crime, like betraying trusteeship, usually lack of returning the property or the refusal of returning it, even by the demanding of the owner can be a proof of the crime. In this subject which began from intellectual and subjective management and is revealed through objective act which reveal the ill will, we can say that appropriation or taking over, became real when it is accompanied by objective or physical act. (Habib Zadeh, 2012). Therefore, withdrawal and appropriation are both the confirmation of the criminal act of embezzlement which will appear as an action (positive behavior); therefore, leaving the action won't create the financial pillar of this crime. In sum, discovering and proving of abstraction is related to revealing the way of taking over and manipulating the property, which in different cases can be varied.

\subsection{Destruction}

The jurists have define destruction or to destruct as partial or general destroying or damaging of the property. The destruction can be made by ruining, burning, breaking and etc. the type of destruction is not important in the nature of the act. Therefore, demolition and burning can be the confirmations of destruction. Based on these facts, embezzlement is the act which will take out the property from the aspect of exploitation or make an imperfection in the property which will decrease its primary value (Katozian, 2011). The lawmaker in provision 1 of the article 5 of intensification law has considered the purposeful destruction of public property as the physical act of embezzlement, this provision state that "In case of purposeful destruction of property besides guaranteeing, the criminal will be convicted with the embezzlement. From this generalization we can conclude that the destruction of property, whether it is purposeful or not, or whether it 
was given to the employee of the government or not, will be included in the provision of the mentioned article. Although the legislator has issued an order for the destruction of government and personal property in article 675 and the next articles of Islamic punishment law, but it seems that provision 1 of article 5 of the mentioned law about all the cases of destructing the government property is not valid. Therefore, by considering the records of the legislator from one point and the relationship between the decrees of the mentioned provision with the next article from another point, here we should only consider the destruction of properties which were given to the employees in accordance with their job (Habib Zadeh, 2012).

\section{Conditions and Circumstances}

For the substantiation of embezzlement there are some conditions which should be met, some of these conditions are related to the subject of the crime and some are related to the criminal. Also, some of these conditions are related to the circumstances of the crime, which will be discussed briefly:

\subsection{Movability and immovability of the property}

One of the other elements of the financial pillar of embezzlement is the property of embezzlement which can include funds, demands, Cheques, stocks, documents, expensive papers and etc. which are the subjects in abstraction crime. Now, the question arises itself that whether the property is movable or not can be the subject of the crime or not? In order to answer this question we should evaluate the terms which are used in legal texts. In related regulations to embezzlement, the legislator uses the terms "funds, demands, cheques, stocks documents and expensive papers" declaring the subject of the crime. Analyzing these terms has created two conclusions among the jurists.

\subsubsection{Substantiation of embezzlement in movable and immovable property}

Some believe that the subject of the embezzlement is whether the property is movable or immovable. They argue that embezzlement is a special form of betraying trusteeship and the legislator has stipulated the inclusion of betraying trusteeship of movable and immovable property in the article 674 of Islamic punishment law. Therefore by considering the stipulation of the legislator about betraying the trusteeship, there is no doubt that embezzlement has a similar condition with betraying trusteeship (Mirmohammad sedeghi, 2013; Noorzadeh, 2003). In another expression by using the priority criteria between article 674 and article 5 of intensification law and by considering the predication of the word property, the subject of the case can be movable or immovable property. (Shambayati, 2012)

\subsubsection{The theory of specifying the embezzlement to movable property}

Regarding this matter some jurist has stated that It might said that at the first impression, by considering the term "and other properties", the regarding property in each crime be a movable or immovable property. It seems that holding to this predication about illegal act is justified, but this predication can't be acceptable in regarding to embezzlement.Although there seems to be a lot of differences between embezzlement and betraying trusteeship, but we can't adapt all the conditions and the circumstances of betraying the trusteeship that the legislator has assigned to embezzlement. Because there is a lot of disagreement among the jurists about the principle of whether immovable properties are included in betraying the trusteeship or not. The majority of jurists believe that immovable properties can't be included in the subject of betraying the trusteeship (Mir Mohammad Sadeghi, 2013). Also, the legal office of indicator has agreed about this subject. (Article of intensification of the punishment of bribery, embezzlement and fraud criminals) doesn't include immovable properties such lands, houses and gardens and it only include movable properties (Shahri \& Setodeh, 2005). Also, some jurists believe that it is more valuable to protect the movable property, because the confirmation of immovable property will provide them with enough and necessary support, and they will not face the threat of destruction very much, but the movable property because of the ease of transferring pose more threat to them. Also, lack of punitive support of immovable property will immune them from remonstrance. The non-punitive support of movable property is much lesser than immovable property, for example the rule of manipulation both support the owner and the criminal (Shokri and et al, 2013). Finally, these group believe that the crime of embezzlement, like thievery has no confirmation in the immovable property. Because the immovable can't be grabbed and by considering the literal meaning of embezzlement and its idiomatic meaning in jurisprudence and the fact that embezzlement in our law is considered a special form of betraying the trusteeship and the fact that we can't "withdraw" the immovable property, therefore these group state embezzlement 
crime will only include the immovable property (Keshavarz, 2008).

\subsection{Delivering the property to the perpetrator}

For the substantiation of embezzlement the property of the subject of crime should be formerly delivered to the perpetrator or should be in his possession. This condition has a common aspect with the crime of betraying the trusteeship. Delivering the property means to put the property under the control or possession of others. Therefore, delivery is a conditions and a purposeful act in which it causes the prevention of someone possessing and finding a new possession for another person (Katozeyan, 2012)( Shahidi 2013). Therefore, the delivery of the property should meet the following circumstances in order to be the origin of enough juridical remnants in order to commit an embezzlement crime. First, the property should be given to the employee as a trust not for him to possess. In another expression the possession which is caused by the employee domination over the property should be the possession by other party. Also, if the property is delivered temporarily to the employee, he has no control or domination over it and interference with that property will be mostly considered as stealing and thievery rather than embezzlement (Habib Zadeh, 2012; Hosni najib, 1992). For example, if searching officers take the belongings of the person being searched during an inspection he will be committing a thievery. Secondary, the act should be performed in the right form and within the legal framework. For instance if an agent out of legal framework force the owner of the property to deliver his property and later on the agent uses that property, his action will be considered as thievery by force or illegal possessing, not embezzlement. Third, the deliverance of property should be in accordance with the employees' occupation, meaning that there should be a reasonable relationship between the job and the property which is delivered to the employee. We can consider the above mentioned crimes as betraying the trusteeship. Therefore, the employee should have an administrative commitment toward the property. As the legislator stated, this commitment can only occur if the property is given to the employee in accordance with his profession. Therefore, if someone based on his administrative possession- not his profession- can access and possess the property, his action will be considered as stealing or thievery and doesn't include embezzlement or illegal seizing (MirMohammad Sadeghi, 2013; Slameh Mamon, 2001).

\subsection{Belonging of the property to public organizations or personal individuals}

From the aspects which will connect embezzlement crimes to property crimes is the fact that the property which is the subject of the crime, should belong to other person, and if the property belongs to the commit, it will have no punitive topics except if the property is internment (subject of article 663 of Islamic punishment law). Generally the property should belong to the government or the organization in which the employee work for. In another expression, the property of the crime is the right of public, government or public organizations. Therefore, the subject- matter of embezzlement can be government or public property or in commandment of government or public property.

\subsection{Employee of the government or being in the commandment of the government employee of the criminal}

Generally the characteristics of people have no effect on their punitive responsibility, and based on the principle of equality punishments, all people are equally responsible in front of the law, and they will be punished if they violate the law. But in some cases the legislator considers the existence of special cases in order to confirm the crime. Therefore, we can state that one of the effective conditions of confirming a crime in embezzlement is the fact that the criminal be the employee of government or be in the commandment of government employee.

\subsubsection{The concept of government employee}

In administrative laws the government or public employee has been defined differently and his legal condition have been analyzed from different aspects. But in the interpretation of punitive texts and laws we can't consider the criterion of administrative laws as the main criterion for this dimension and we should discover the intentions of legislator and find the exact purpose and meaning of the used terms by the legislator (Aboahmad, 2005; Tabatabaie Motameni, 2011; Talaremi Emami and sangari Korosh, 2012). In article 5 of intensification of bribery, embezzlement and fraud punishment law and article 598 of Islamic punishment law, the legislator have categorized and described the groups that can be included in embezzlement and they are: 1- Employees and personnel of government office and organizations 2- Employees and personnel of computation bureau 3- The owners of juridical bases 4- Employees and personnel of armed forces 5Employees and personnel of councils 6- Employees and personnel of government organizations and factories and 7- 
Employees and personnel of organizations and factories which are dependent on government. Therefore, any of the above mentioned people who work for the government are considered government employees, whether their relationship with government is official, contractual, promissory, daily paying or etc. Based on this classification which might be far from the existing concepts in administrative laws, the employees and personnel of government offices and organization (The total of executive forces), the owners of juridical bases (The total of juridical forces), the bureau of computation and the members of Islamic Council (The total of legislative force) and in general the members and employees of three branches of ruling and also the employees of government factories and the organization which are dependent on government are considered as the government employees. Also, it should be mentioned that in case of armed forces employees and in case of embezzlement the article 94 of punishing the armed forces law of the Islamic republic of Iran which was approved in 2003 will be applied.

\subsubsection{The concept of an individual in the commandment of governmentemployee}

Except the mentioned personnel and employees of government, the rest of the people who work in a non-governmental institutions and organizations, will be considered the individuals in the commandment of government. Therefore, the individuals in the commandment of government are: 1- Mayoralty and their dependent factories 2- The poor foundation and the devotees of the Islamic revolution 3- Red Cross 4- Imam's assistant committee 5- Martyr foundation of Islamic revolution 6- The national Olympic committee of Iran 7- The fifteenth of khordad foundation 8- The organization of Islamic advertisement 9- The organization of social security and 10- The organization of special diseases. Also, the employees and personnel of the mentioned organizations and the agents of social services which are defined in article 3 of trial and punishing the agents to social services law that was approved in 1936, these people are considered as the commandment of government employees (Moosa Zadeh, 2011).

\section{Criminal Consequence}

The embezzlement is a conditional crime and therefore it require a consequence and the consequence in this crime is a damage or the loss that will be made upon the property and the owner of the property which in most cases are the public institutions or government property. In another expression the proscription of government or general institutions from the property which they have given to the employee is a consequence that is caused by embezzlement, and if this consequence does not occur the act of embezzlement is not committed, whether the criminal or other person benefit from this act. Based on these facts it is necessary to be a conditional relationship between committal act and the consequence. If this condition doesn't exist we can't call a person a defalcator. For instance, if an employee put a cash in his bag in order to get it out of his office, and in the meanwhile someone seize the opportunity and steal the bag of the employee or the bag fall from a high place and the stuff which are within the bag get out, the proscription of the owner from his property is confirmed, but there is no conditional relationship between this consequence and the act of the employee. Based on these facts even if we consider this person civilly responsible, from the viewpoint of punitive law, we can't call him a defalcator. But in illegal possession this condition is not the same, because in this case the act of the criminal is composed of whether he has made a damage or not, or even his action might have some benefit for the government but anyway the employee will be legally pursued, because of manipulating the government property. For instance, if an employee spends a budget in a different place and even if his action is in the benefit of the government, he will be charged with illegal act based on the clear order of article 598 of Islamic punishment law.

\section{The Psychological Element of Embezzlement}

Embezzlement is considered a purposeful crime and morally it is equal with betraying the trusteeship. The spiritual pillar of this crime is the fact that the criminal know he doesn't deserve the property and he purposefully commit the crime. The first step in abstraction is that the criminal have the knowledge that the property doesn't belong to him and he doesn't have the right to manipulate the property. Therefore, if the criminal with this thought that the property belong to himself, start to possess the property, the law can't pursue him as a defalcator. Secondly, the criminal should have a purpose behind embezzlement and damaging the government property (Habib Zadeh, 2012; MirMohammad Sadeghi, 2013). Therefore, in order to confirm embezzlement the criminal should have both general and specific ill-will and if it is proven that he lack these psychological conditions, we can't consider his crime as embezzlement (Ardebili, 2013). Of course, when it is proven that the criminal had the purpose of withdraw and possess the property, there is no need to prove the specific ill-will, because anyone who tries to possess the property for his own or others benefit, naturally have the 
purpose of damaging the owners property.

\section{Penalty}

The main penalty of embezzlement is imprisonment (which differ based on the money which was taken), pecuniary penalty of paying the double of the property price and the temporary or permanent discharge of government services. But the main penalty of forming or leading an abstraction is imprisonment between 15 years or imprisonment for life and the permanent discharge of government services. In the last section of article 4 it has been mentioned that if it is confirmed that the formers or the leaders of abstraction, bribery and fraud are corruption on earth, their penalty will be execution. If it is confirmed that the criminals have made corruption on earth they will be trialed in the Islamic revolution court, because these type of crimes are the especially of this court (Khaleghi, 2013).

\section{Conclusion}

In case of subject and dependency of embezzlement we have reached this conclusion that not only it includes movable property but also immovability property as well, therefore the legislator should make sure that all courts follow a united procedure and prevent the different inferences which are made from the term "other properties" in article 5 of intensification the punishment of embezzlement bribery and fraud crimes law. The factors and motivations which have caused the possessing of others people property as a sub-category of embezzlement, they can be in extension inferred to the people who take over the property of joint stock factories, personal cooperatives and etc. For instance, if the government gives the permission to artificial and natural people to build private banks, and these people based on legal framework start to build these banks and people based on the general believe of government supervision, put their property in these banks, it seems that the legislator in order to make a punitive protection of these properties and in order to guarantee the economic, political and cultural activities can consider the appropriation of these properties as embezzlement.

\section{References}

Aboahmad, A. (2005) .Administrative Rights of Iran.

Ardebili, M. A. (2013). General criminal law, mizan publication, Twentieth Edition, Volume II, Tehran.

Shahri, G. and Setodeh, S. (2005).Opinions of the Legal Department of the judiciary in criminal matters, Official Newspaper,Volume II, Tehran.

Goldozian, I. (2013). Specific criminal law, University Publication, Nineteenth Edition, Tehran.

Habbibzadeh, M. J. (2012). The analysis of fraud and malversation crimes, ,Dadgostar Publication, Tehran.

Hosni najib, M. (1992). Description of the Penal Code, Arabian Dar alnehza.

Katozian Nasser, 2011. Obligations outside the contracts, Publishing Company, ....Sixth edition, Tehran.

Katozian, N. (2013). Recurring contracts, Enteshar Publication, Second edition, Tehran.

Keshavarz Bahman, 2008. gloss Chastisings, Dadgostar Publication,Tehran.

Khaleghi, A. (2013).Criminal Procedure, Page 200.Shahre danesh Publication, Second edition, Tehran.

Mirmohammad sedeghi, H. (2013). Crimes against wealth and property, Mizan Publication, , Eleventh Edition, Tehran.

Noorzadeh, E. (2003). analyze of the abstraction and Illegal possession in The state property , Arian Publication Tehran.

Omar mosa, A. (1991). Crimes against public property, Eskandarieh, Aljami Residence of Thinking,

Habbibzadeh, M. J. (2013). Specific criminal law, , Samt Publication, Tehran.

Saleh, N. A. (1992). abstraction, Amman Residence of Thinking.

Shahidi, M. (2013).Civic law 6,Majd Publication, Sixth edition, Tehran.

Shambayati, H. (2012). Specific criminal law, Zhobin Publication, Sixth edition,, Volume II, Tehran.

Shokri, R. and Siros G,(2013) Islamic Penal Code In the current legal order, Mohajer Publication, Tehran.

Slameh Mamon, M.(2001). Penal Code, Arabian Residence of Thinking, First Edition,

Tabatabaie Motameni Manochehr, Administrative law, Samt Publication, Eleventh Edition, Tehran,2011 ,Toos Publication Sixth edition, Tehran.

Talaremi Emami \& Ostvar sangari K. (2012). Administrative law, Mizan Publication, Tehran. 